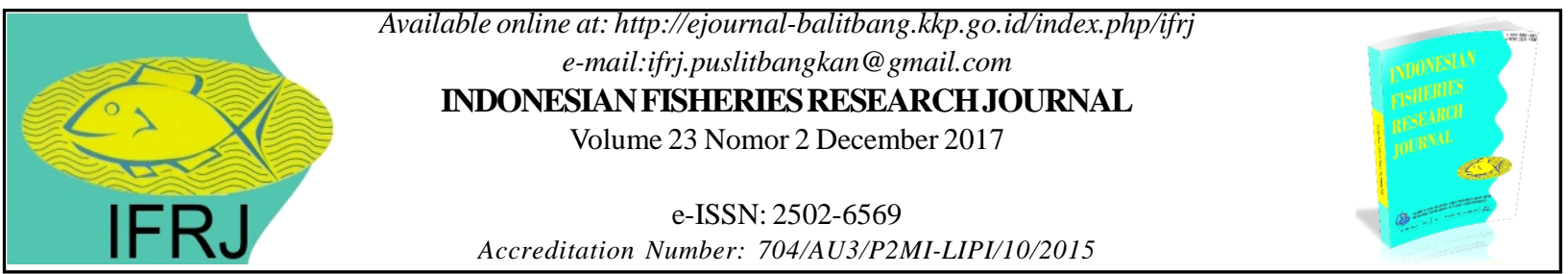

\title{
FISHERIES AND ENVIRONMENTAL IMPACTS IN THE GREAT JAKARTA BAY ECOSYSTEM
}

\author{
Hari Eko Irianto*1,2, Sri Turni Hartati ${ }^{1}$ and Lilis Sadiyah ${ }^{1}$ \\ ${ }^{1}$ Center for Fisheries Research, JI. Pasir Putih II, Gd. II, BRSDM KP, Ancol Timur Jakarta Utara-14430, Indonesia \\ ${ }^{2}$ Research and Development Center for Marine and Fisheries Product Processing and Biotechnology, \\ JI. Petamburan VI, Jakarta Pusat-10260, Indonesia \\ Received; March 14-2017 Received in revised from September 18-2017; Accepted January 09-2018
}

\begin{abstract}
The Great Jakarta Bay Ecosystem (GJBE) supports the economic growth for the surrounding community, including fisheries sector. This large ecosystem is consisted of two coastal ecosystems, i.e. Jakarta Bay and Thousands islands. There are only traditional fisheries operating either in Jakarta Bay or Thousand islands. Some economically important fisheries include shrimp, demersal and small pelagic fisheries, which are caught using different fishing gears, either active or passive fishing gears. There are some serious concerns related to the fish resources and habitat degradations in the GJBE, which in turn can cause the decrease in fish population and fish species diversity, respectively. CPUE and catch composition of the fixed lift nets, sero and fixed gillnet fisheries were obtained from the observations in 2006 and 2014. In addition, to determine the level of pollution, tissue samples were collected for green mussel (Perna viridis), blue swimming crab (Portunus pelagicus) and white-spotted spinefoot (Siganus canaliculatus) in 2009. The CPUE trend and catch composition showed that overfishing might have been occurring in the Jakarta Bay. The histological study on gill tissues of the three species shows that the Jakarta Bay has been polluted. Several efforts have been done to address the problems, including sea farming, habitat rehabilitation (artificial reef and mangrove restoration), marine conservation area and fish shelter, restocking and sea ranching.
\end{abstract}

Keywords: Jakarta Bay; Thousand Islands; fisheries

\section{INTRODUCTION}

The Greater Jakarta Bay Ecosystem (GJBE) is located between $106^{\circ} 20^{\prime} \mathrm{E}-107^{\circ} 03^{\prime} \mathrm{E}$ and between $5^{\circ} 10^{\prime} \mathrm{S}-6^{\circ} 10^{\prime} \mathrm{S}$, which is under Banten Province, the Special Capital Region of Jakarta and West Java Province (Arifin, 2004). This large ecosystem is formed by two coastal ecosystems, i.e. Jakarta Bay (Teluk Jakarta) and Thousand Islands (Kepulauan Seribu) (Williams et al., 2000). The Jakarta Bay is bordered by the capes of Tanjung Krawang to the east and Tanjung Pasir/Tanjung Jawa to the west (Arifin, 2004). There are thirteen rivers flowing into and bringing pollution to the Jakarta Bay, i.e. Angke, Bekasi, Cakung, Cidurian, Ciliwung, Cikarang Cimancuri, Ciranjang, Cisadane, Citarum, Karawang Krukut and Sunter (Arifin, 2004, Nuraini et al., 2011). Whereas, the Thousand Islands is under the Special Capital Region of Jakarta, consisted of 110 small islands (Arifin, 2004, Amri \& Agus, 2011).
The GJBE has significant roles to support natural, supply, recreational and waste regulating services. The GJBE also supports the economic growth for the surrounding community, especially from fisheries sector, which mainly from capture fisheries as well as from aquaculture (Arifin, 2004). The ecosystem provides high marine species diversity, included 362 and 166 fish species in the Jakarta Bay and Thousand Islands, respectively (Suharsono et al., 1998).

There are only traditional fisheries operating either in Jakarta Bay or Thousand islands. Some economically important fisheries include shrimp, demersal and small pelagic fisheries, which are caught using different fishing gears, either active fishing gears, such as, pelagic danish seine (payang) and mini trawl ( $a r a d)$, and passive fishing gears, as lift nets (bagan), trap (bubu), guiding barrier (sero) and gillnet (jaring insang) that have been used since 1970s with muroami as the dominant fishing gear at that time. The latter 
fishing gear dropped in number, but increased again in 2000s, which has resulted change in the catch composition (Hufiadi et al., 2011).

There have been some serious concerns related to the fish resources and habitat degradations in the GJBE, which in turn can cause the decrease in fish population and fish species diversity, respectively. Overfishing is one of the fisheries problems in these large ecosystems, whereas the habitat degradation included coral reef destruction and water pollution (Hufiadi et al., 2011). Several efforts have been done to address the problems, including restocking, sea farming, sea ranching, habitat rehabilitation (artificial reef and mangrove restoration), Marine Conservation Area and fish shelter (Anon., 2011b). This study was aimed to provide the fisheries profile and enviromental aspects of the Great Jakarta Bay Ecosystem.

\section{MATERIALS AND METHODS}

Data used in the analysis were collected during the periods of 2006, 2009 and 2014 in the Jakarta Bay and Thousand Islands. In the years of 2006 and 2014 , observations were undertaken by the Research
Institute for Marine Fisheries (RIMF) and Research Center for Fisheries and Marine Conservation (RCFMC, which is now called as Center for Fisheries Research), respectively, both in Kamal (Jakarta Bay) and Pari (Thousand Islands). The average CPUE and catch composition of the fixed lift nets, guiding barrier (sero) and fixed gillnet fisheries were obtained from the observations (primary data). Whereas in 2009, the gill and liver tissue damages of green mussels (Perna viridis), blue swimming crab (Portunus pelagicus) and white-spotted spinefoot (Siganus canaliculatus) were collected by RIMF from Kamal fish landing place (the Jakarta Bay) and Pari Islands (Thousand Islands) (Table 1). It was assumed that those samples taken from Kamal fish place represented biota from environmentally degraded areas, whereas those samples from Pari Island represented biota from non-degraded areas. Those of 3 tissue samples were histologically analyzed following Prihatiningsih et al. (2008) in the laboratory of RIMF. In addition, fisheries data including number of fishers, number of vessels, number of fishing gears and catch were gathered from the statistics of capture fisheries - DKI Jakarta, 2013 (Anon., 2014).

Table 1. Number of tissue samples collected for the preparation in 2009

\begin{tabular}{lccc}
\hline & $\begin{array}{c}\text { White-spotted } \\
\text { Spinefoot (Siganus } \\
\text { canaliculatus) }\end{array}$ & $\begin{array}{c}\text { Green Mussels } \\
\text { (Perna viridis) }\end{array}$ & $\begin{array}{c}\text { Blue Swimming } \\
\text { Crab (Portunus } \\
\text { pelagicus) }\end{array}$ \\
\hline Jakarta Bay (Kamal) & 40 & 130 & 103 \\
Thousand Islands (Pari Island) & 98 & 143 & 31 \\
\hline
\end{tabular}

\section{RESULTS AND DISCUSSION Results}

\section{Fisheries in the Jakarta Bay and Thousand Islands}

The fishers in both regions use fishing vessels with size less than $10 \mathrm{GT}$, while a few bigger fishing vessels are from outside of the Jakarta Bay and Thousand Islands but landed their catches in North Jakarta. The total number of fishing vessels less than $10 \mathrm{GT}$ in 2012 were 2,836 units- consisted of 1,564 and 1,272 units from the Jakarta Bay and the Thousand Islands, respectively (Figure 1). The dominant fishing gears used in the Jakarta Bay were harpoon and others, while in the Thousand Islands were traps and longline (Figure 2).

The annual fish production shows an increasing trend between 1992 and 2012 (Figure 3). Lift nets and drifting gillnet dominated the catches with an average of 27,143 and 18,821 tonnes per year, respectively, but the highest catch $(43,707$ tonnes per year) was by other gears category ("Others"). 


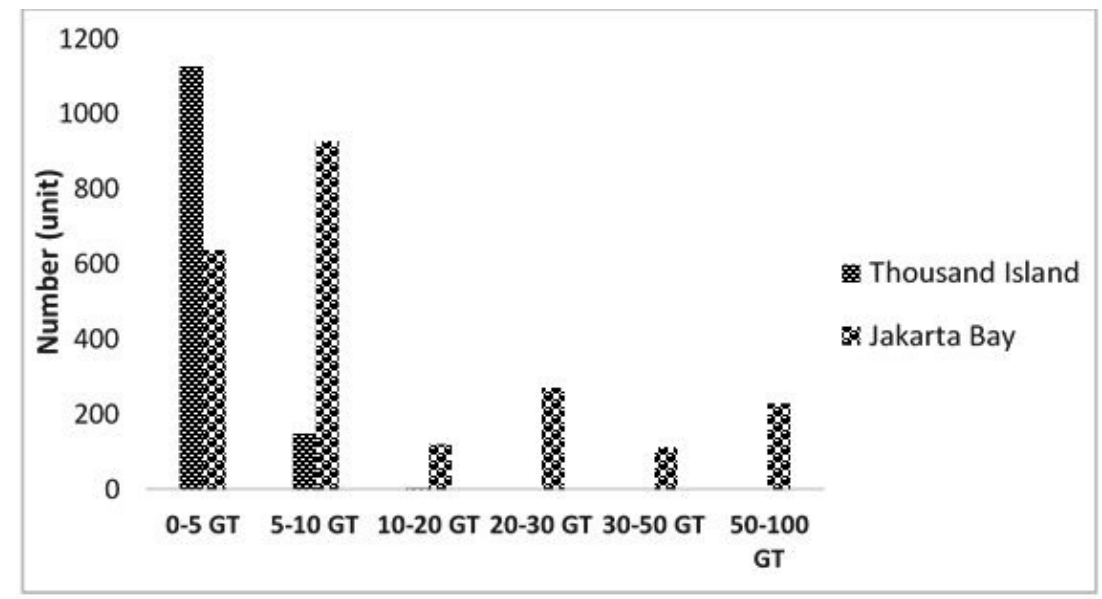

Figure 1. Number of vessels by size based in the Jakarta Bay and Thousand Islands in 2012. Source: Anon. (2014).

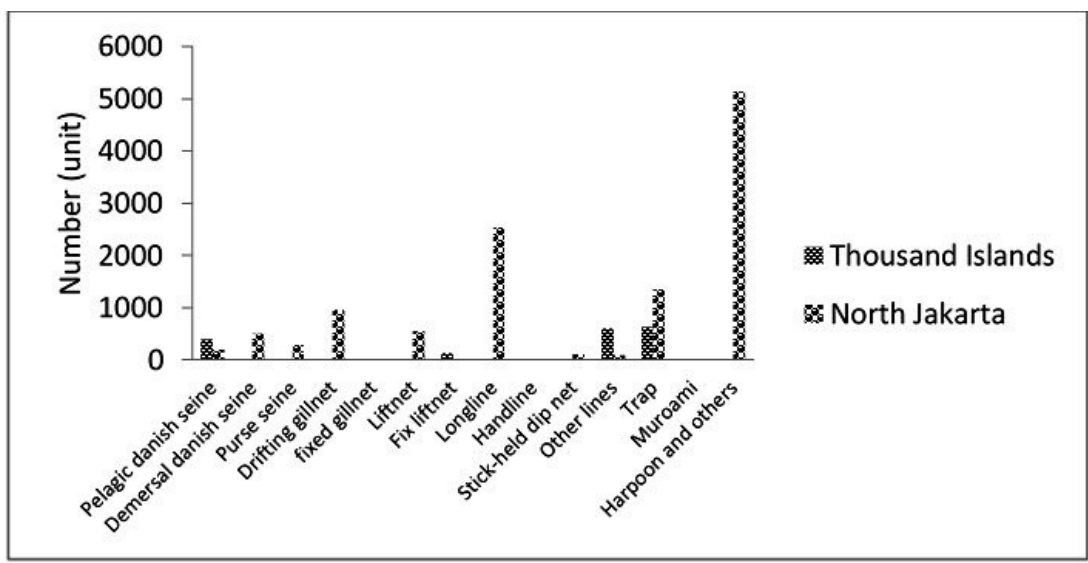

Figure 2. Number of fishing gears used in the Jakarta Bay and Thousand Islands. Source: Anon. (2014).

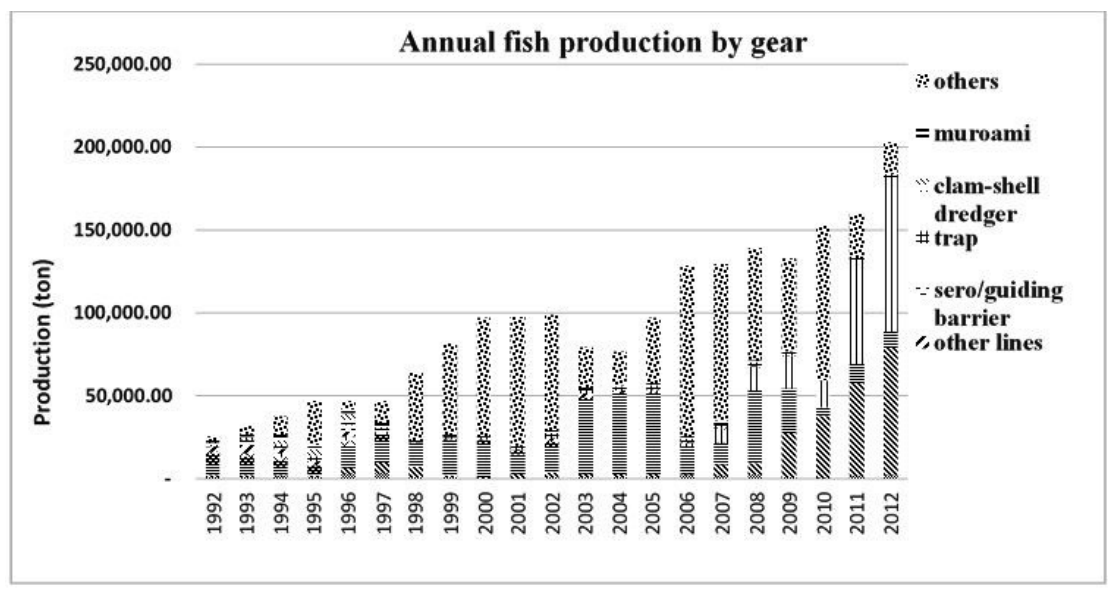

Figure 3. Annual fish production by gear. Source: Anon. (2014).

A decrease trend in catch per unit effort (CPUE) was found in several gears including fix liftnets, fixed gillnet and sero. The average CPUE of fix liftnets operated in the Jakarta Bay during 2006 in the east and west monsoon were 50 and $70 \mathrm{~kg} /$ lift nets/day, respectively, with the CPUE in the east monsoon decreased to around $30 \mathrm{~kg} /$ lift nets/day (Figure 4). The average CPUE during the east monsoon decreased to $32 \mathrm{~kg} /$ lift nets/day. However, higher average CPUEs were found for the Thousand Islands during east and west monsoons in 2006, i.e. 96 and $176 \mathrm{~kg} /$ lift nets/day, respectively. 
The average CPUE of fixed gillnet in the Jakarta Bay during 2006 in the east and west monsoons in 2006 was 45 and $115 \mathrm{~kg} / \mathrm{vessel} /$ day, respectively, and decreased in 2014 to 26 and $33 \mathrm{~kg} /$ vessel/day, respectively (Figure 5). Similarly, the average CPUE of sero in the Jakarta Bay during 2006 east and west monsoons decreased from 30 and $10 \mathrm{~kg} /$ sero/day, respectively to 14 and $8 \mathrm{~kg} / \mathrm{sero} /$ day, respectively, in 2014 (Figure 6).

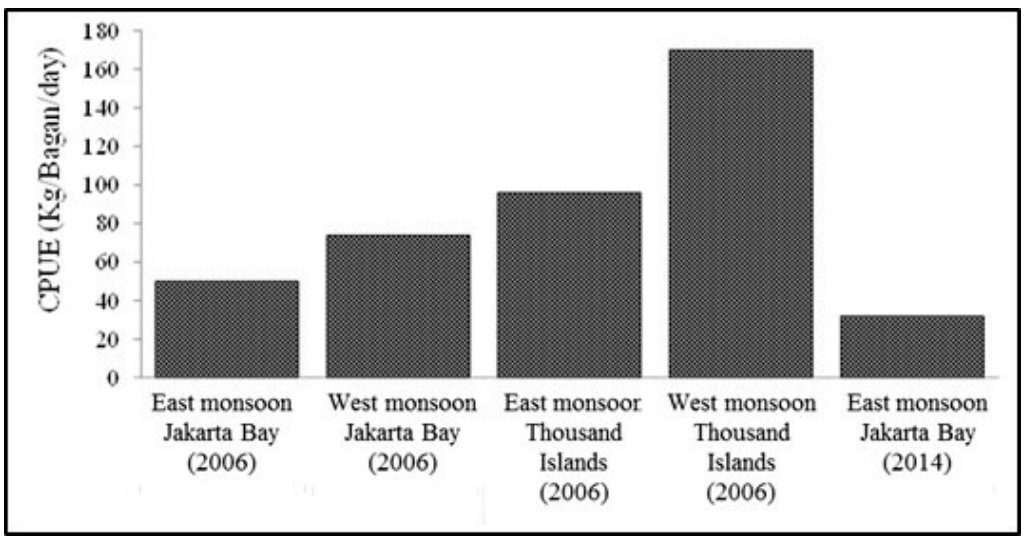

Figure 4. Average CPUE of fix liftnets (bagan) in 2006 and 2014 by season and area.

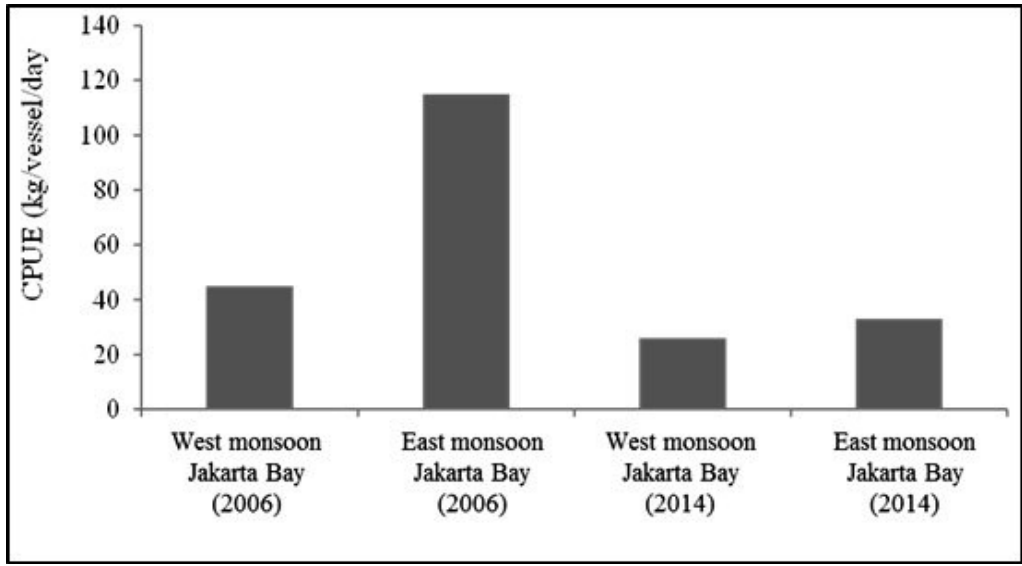

Figure 5. Average CPUE of fixed gillnet (kg/vessel/day) operated in the Jakarta Bay in 2006 and 2014 by season.

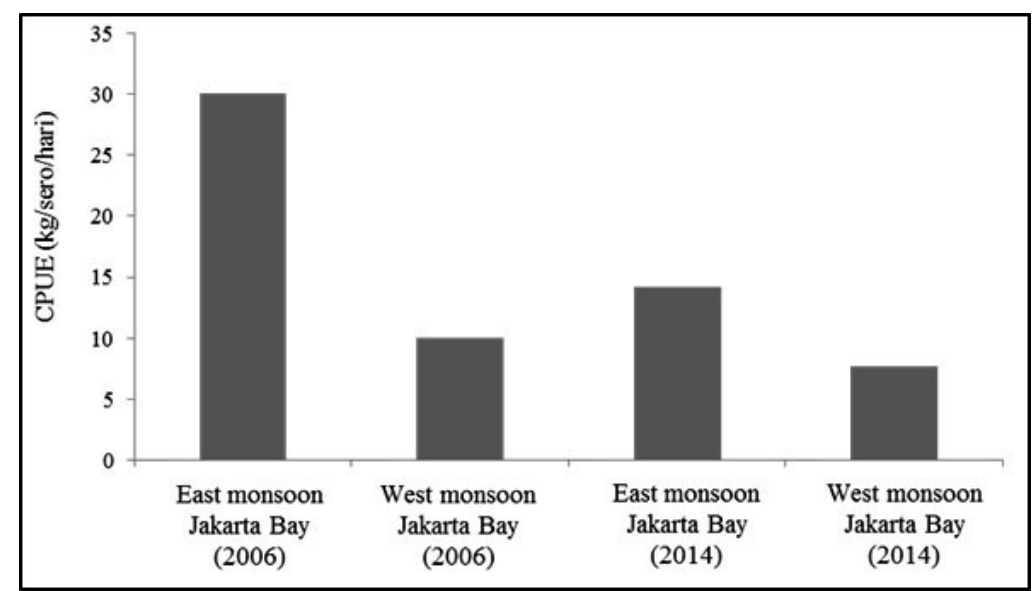

Figure 6. Average CPUE of sero operated in the Jakarta Bay in 2006 and 2014 by season. 
The three passive gears catch large amount of trash fish. (small sized fish including juvenile). The high proportion of trash fish being caught was likely due to their fishing grounds overlapped with the spawning or nursery areas. Fix liftnets operated in the Jakarta Bay caught the trash fish during east and west monsoons in 2006 about $64 \%$ and $43 \%$ of the total catch, respectively, and during east monsoon in 2014 around 69\% (Figure 7). The trash fish caught this gear (across whole year) in the Jakarta Bay comprised of about $60 \%$ pelagic fish, $30 \%$ demersal fish and $10 \%$ non-fish However, only small proportion for trash fish being caught by fix liftnets in the Thousand Islands in 2006 , around $5 \%$ of the total catch during west monsoon and no trash fish was reported in east monsoon 2006.
Different dominant species were caught by fixed gillnet in 2006 and 2014, mostly Rastrelliger sp in 2006, and trash fish and Sciaenidae spp. in 2014 (Figure 8). The proportion of trash fish relative to the total fish caught by fixed gillnet increased for both seasons, from less than $5 \%$ in 2006 to more than $30 \%$ in 2014 (east monsoon) and from 20\% in 2006 to $35 \%$ in 2014 (west monsoon), respectively (Figure 8). The trash fish caught by fixed gillnet comprised of about $80 \%$ pelagic fish, $19 \%$ demersal fish and $1 \%$ non-fish. This supports that the Jakarta Bay can provide a good supply of recruits for pelagic fish.

Catches of sero were dominated by trash fish either during east and west monsoons in 2006 and 2014 (Figure 9 ). The trash fish comprised of $42 \%$ of nonfish, $34 \%$ pelagic fish and $24 \%$ demersal fish.

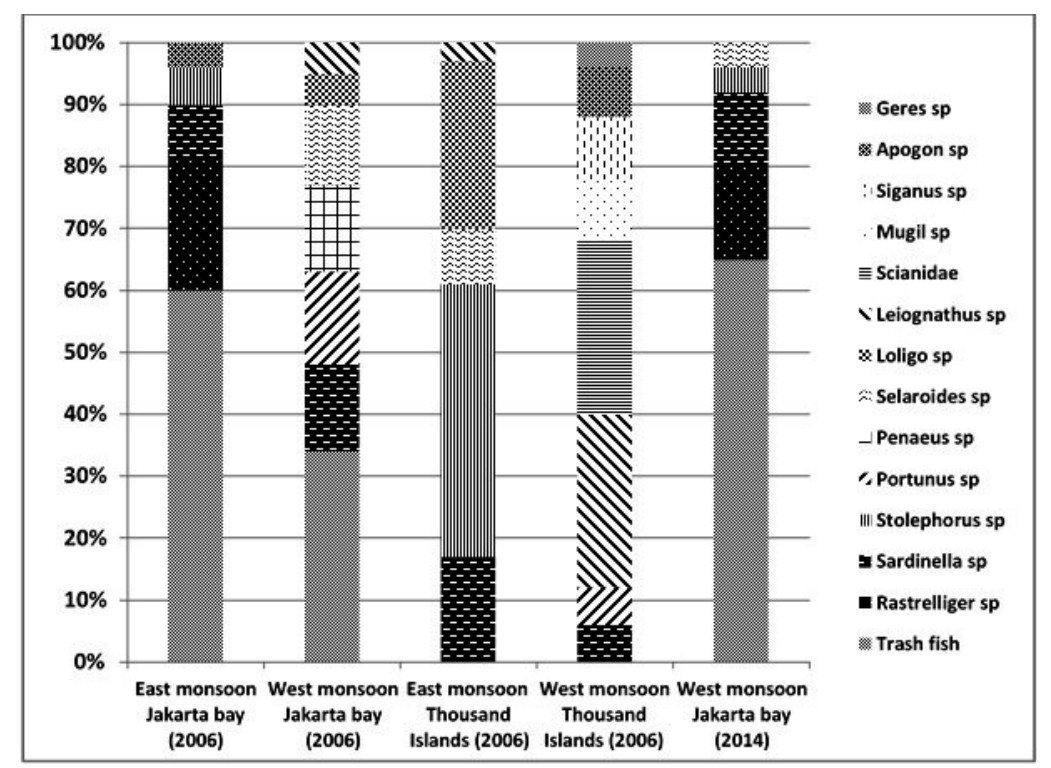

Figure 7. Catch composition of fix liftnets in the Jakarta Bay and Thousand Islands by season.

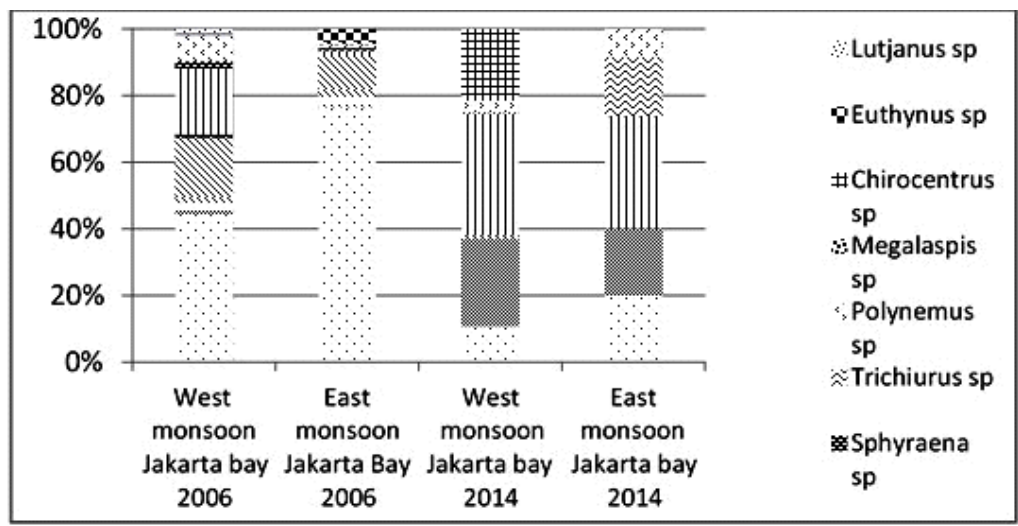

Figure 8. Catch composition of fixed gillnet in the Jakarta Bay by season. 


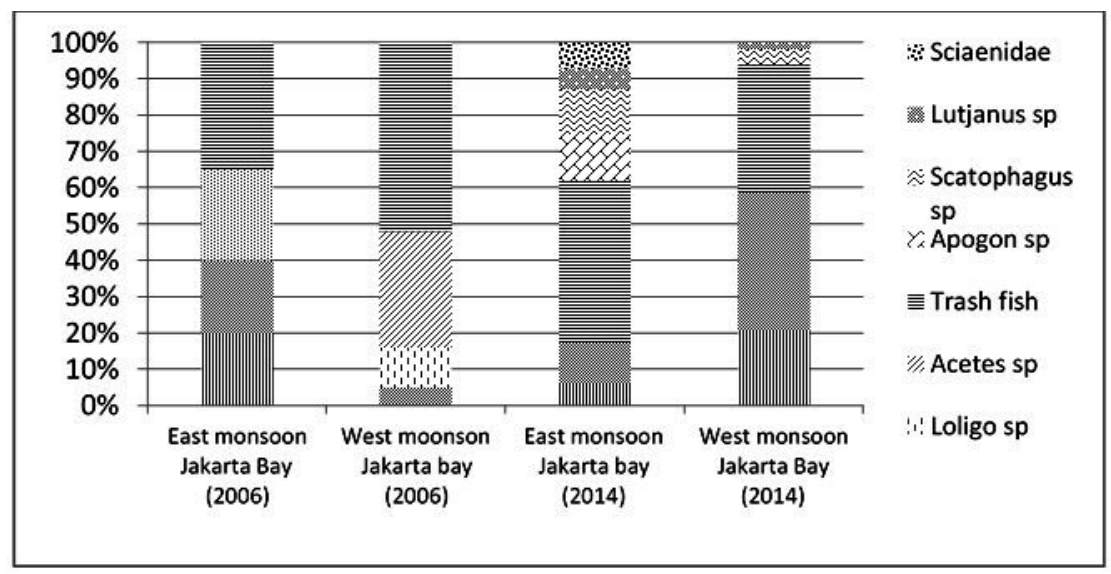

Figure 9. Catch composition of sero in the Jakarta Bay by season.

\section{Effect of Pollution on Fisheries}

The main environmental problem of the Jakarta Bay is the pollutants originated from 13 rivers that enter into the bay. The pollution level can be indicated from, among other things, changes in microanatomy structure of gill and liver tissues. Based on the histological study, the microanatomy structures of gill tissues of green mussels (Perna viridis) from the Jakarta Bay is abnormal (Figure 10a), but normal for the gill tissue samples from the Thousand Island (Figure 11a). Similarly patterns were shown also for blue swimming crab (Portunus pelagicus) and whitespotted spinefoot fish (Siganus canaliculatus) (Figures 10b-c, 11b-c).

Furthermore, the same of abnormal condition also found in the microanatomy structure of liver tissues cytolysis and karyolysis tissue structures) of green mussel (Figure 12a), blue swimming crab (Figure 12 b) and white-spotted spinefoot fish (Figure $12 \mathrm{c}$ ) collected from the Jakarta Bay compared with the normal condition of those 3 samples collected from the Thousand Islands (Figures 13a-c). (a)

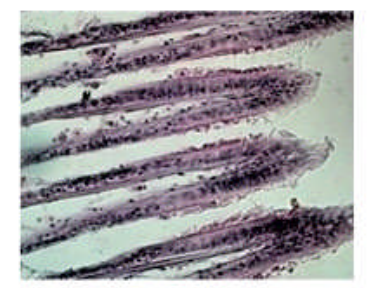

(b)

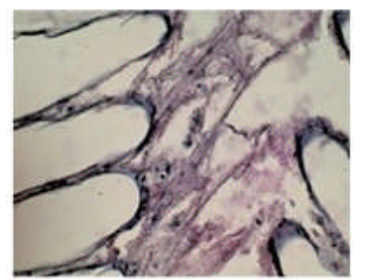

(c)

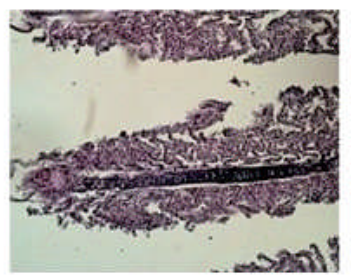

Figure 10. Microanatomy structures of gill tissue of (a) green mussels (Perna viridis), (b) blue swimming crab (Portunus pelagicus) and (c) white-spotted spinefoot (Siganus canaliculatus) in the Jakarta Bay.

(a)

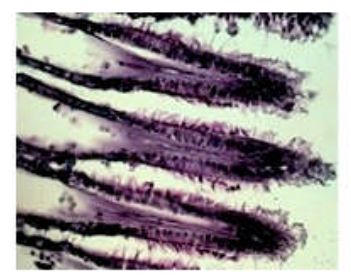

(b)

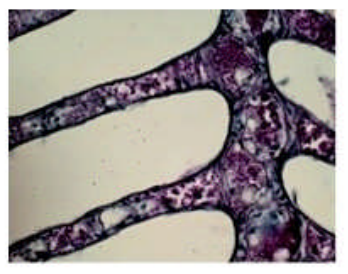

(c)

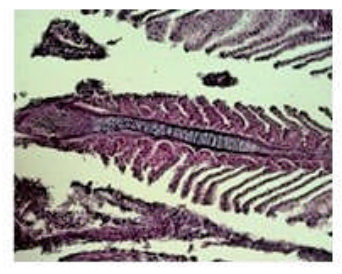

Figure 11. Microanatomy structures of gill tissue of (a) green mussels (Perna viridis), (b) blue swimming crab (Portunus pelagicus) and (c) white-spotted spinefoot (Siganus canaliculatus) in the Thousand Islands. 
(a)

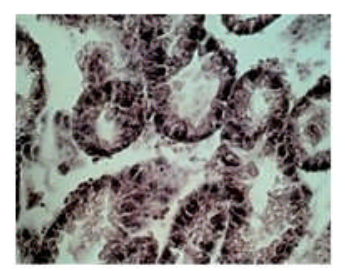

(b)

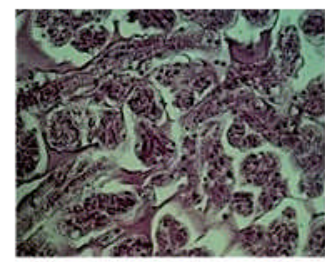

(c)

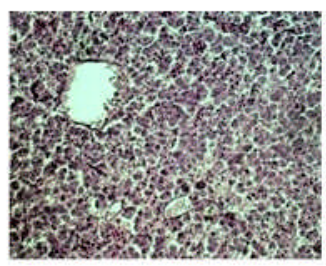

Figure 12. Microanatomy structures of liver tissue of (a) green mussels (Perna viridis), (b) blue swimming crab (Portunus pelagicus) and (c) white-spotted spinefoot (Siganus canaliculatus) in the Jakarta Bay.

(a)

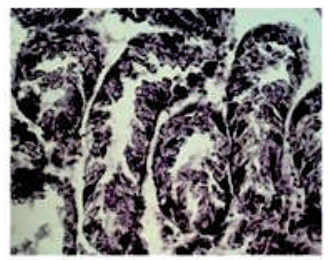

(b)

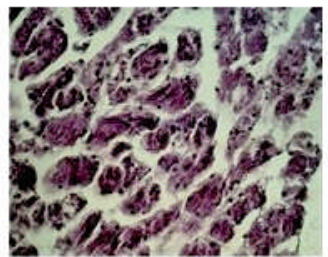

(c)

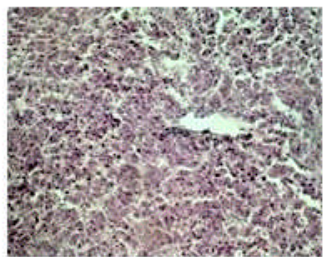

Figure 13. Microanatomy structures of liver tissue of (a) green mussels (Perna viridis), (b) blue swimming crab (Portunus pelagicus) and (c) white-spotted spinefoot (Siganus canaliculatus) in the Thousand Islands.

\section{Discussion}

The fisheries condition in the Jakarta Bay and the Thousand Islands can be indicated from the CPUE trend and catch composition, particularly trash fish proportion. The proportion of trash fish and predator (grouper) can be used as one of fisheries indicator, a high proportion of trash fish and/or a low proportion of predator can indicate that overfishing is occurring. The CPUE of fix lift nets, fixed gillnet and sero in the Jakarta Bay decreased from 2006 and 2014. The CPUE of fix lift nets in the Jakarta Bay was higher than that from the Thousand Islands. These three passive gears caught large proportion of trash fish which comprised of small sized fish including juvenile fish. In addition, in the Jakarta Bay, the fix lift nets caught higher proportion of trash fish compared to that from the Thousand Islands. These suggested that overfishing might have been occurring in the Jakarta Bay.

Anthropogenic pollutants are suspected as the main environmental problem of the Jakarta Bay that impacted the fisheries in the Jakarta Bay. There are several large scale socio-economic activities along $32 \mathrm{~km}$ of coastline in the city of Jakarta, such as Port of Tanjung Priuk, industry, tourism, slum housing, warehouse and fisheries activities in the river-mouths/ estuary, supplying main pollutants and sedimentation (Soebagio, 2001). Terrestrial contamination is estimated to contribute up to $80 \%$ of the pollution in Jakarta Bay (Anon., 2007). About 161 tonnes of litter was transported to the Jakarta Bay from the 13 rivers that filled the area of $514 \mathrm{~km}^{2}$ (Harian Pelita, 2015). It was estimated about $7,000 \mathrm{~m}^{3}$ of liquid waste contained heavy metal, has been discarded into several rivers and transferred into the Bay (Lestari \& Edward, 2004). According to Arifin (2004), within the last 20 years the average concentration of $\mathrm{Pb}$ and $\mathrm{Cu}$ in the sediment increased to be 5 and 9 times greater, respectively, with the highest concentration is distributed in the west and central Jakarta Bay. The physic-chemical parameters showed that the Jakarta Bay is polluted, exceeding the allowable limit for the aquatic biota referring to Ministerial Decree No. 54 of 2004 by the Ministry of Environment, Indonesia. According to Atmaja (2011), in 2004 the mass death of fish and other aquatic biota in the surrounding waters of Ancol and Dadap (Jakarta) is a signal indicating that a high level of pollution occurring in the Jakarta Bay.

Furthermore, impact of pollution in the Jakarta Bay has been found in green mussels that have a role as filter feeder. In aquaculture activities, a highly polluted water condition may cause the early-age of greenmussels being detached. It seems that the pollution also impacts on the microanatomy structures of gill and liver tissues of green mussels (Perna viridis), blue swimming crab (Portunus pelagicus) and white-spotted spinefoot (Siganus canaliculatus) in the Jakarta Bay, causing abnormal tissue structures. Unlike those taken from the Jakarta Bay, the gill and liver tissue samples of the green mussels, swimming crab and 
white-spotted spinefoot taken from the Thousand Islands suggested normal and non-degraded structures. According to Tandjung (1982), the histological study on gill tissues of the three species showed that the Jakarta Bay has been polluted. The serious concerns related to the fish resources and habitat degradations in the GJBE, especially in the Jakarta Bay, can cause the decrease in fish population and fish species diversity, respectively.

Some other problems were found both in the GJBE, i.e. related to mangrove coverage, coral reef and seagrass ecosystems. In the last 10 years, the mangrove coverage in the Jakarta Bay decreased from 340.90 to 232.04 ha (Parawansa, 2007), similarly in Thousand Islands reduced from 4,027 to 150 ha (Anon., 2011a). However, there are still some mangrove forests in the Jakarta Bay (Muara Kamal, Teluk Kamal, Tanjung Kerawang) with relatively high coverage, i.e. between 44.43-60.75\% (RIFEC, 2009).

Coral reefs and seagrass ecosystem play important roles for providing food, nursery and spawning grounds for many species of fish and other marine life (Bengen, 2000). The cause of damage to coral reef, mangrove and seagrass ecosystems in the waters of the Thousand Islands are mostly caused by human activity, garbage from Jakarta, sand mining, and clearing of mangrove forests for settlement and wood charcoal, as well as fishing with destructive fishing gear (Asriyana \& Salwiyah, 2007). In addition, port construction and industrial activities around the Gulf of Banten are considered to eliminate hundreds acres of seagrass ecosystem in the waters around the islands in the Jakarta Bay.

A deterioration of coral reefs took place dramatically in the health of coral reefs in the Thousand Islands between 1985-1995 (Vantier et al. in Cesar, 1996). From 19 coral reef areas in the Thousand Islands observed in 2007 and 2009, only 5 areas were in good health condition, 10 areas in the medium condition and 4 areas in bad condition (Wagiyo \& Hartati, 2013). The coral reefs in the Thousand Islands can be categorized as damage to moderate conditions, with the percentage of the live coral cover ranged from 0 to $49.9 \%$. Entering the 2000 's, about $70 \%$ of coral reefs in the Thousand Islands are in a damage condition, and less than $10 \%$ are in good condition (Anon., 2011b). Coral reefs damage is largely caused by rock mining for building materials, fishing with explosives and toxic chemicals (Santoso, 2010), as well as the fishing gear that is not environmental friendly such as muroami (based on interview with fishers).
Several programs to overcome the crisis of habitat and decrease in stocks of fish resources in the Bay of Jakarta and Thousand Islands have been done by the Provincial Government of Jakarta, NGOs, Research Institutions and related universities. The programs included mariculture in the Thousand Islands through sea farming program with the targets of mariculture development are grouper, milkfish and seaweed, for the local are market in Jakarta and surrounding areas; coral transplantation program focused on the area of marine protected areas (MPAs) around the inhabited islands; artificial reefs as fish habitat and mangrove restoration. Wagiyo \& Hartati (2013) stated that from 7 coral reef areas that have been assigned as MPAs, only in Harapan Island that has bad condition of coral reefs (the coral cover is $24 \%$ ). Other programs that have been undertaken to restore or enhance fisheries are restocking and sea ranching. Restocking of sandfish/sea cucumber (Holothuria scabra) has been done by the RCFMC in Pamegaran Island waters (RCFMC, 2004, RIFEC ${ }^{1}$, 2010).

\section{CONCLUSION}

In order to improve the condition of fish resources in the Jakarta Bay and increase capacity of the Jakarta Bay as the supplier of fish recruits for its surrounding waters, an ecosystem rehabilitation endeavor and conservation area determination especially for several locations that are considered to be spawning and nursery grounds (e.g. Muara Kamal and Tanjung Kerawang) are required. Restriction of the passive gears (fix liftnets and sero), that operate in coastal areas of Kamal and Cilincing that have high larvae and juvenile abundances, is needed. The results showed that the Jakarta Bay is polluted based on the physic-chemical parameters. All these possibly caused the abnormal of gill and liver tissue structures of green mussels, blue swimming crab and white-spotted spinefoot. Real actions to revert the quality of the Jakarta Bay need to be taken, i.e. by reducing the pollutant supplies, such as providing wastewater treatment plants, to prevent further cell/tissue damage that can cause death or even extinction of a biota.

\section{ACKNOWLEDGEMENTS}

This paper is part of the internal research programs under the Research Institute for Marine Fisheries (RIMF) and Research Center for Fisheries management and Conservation (RCFMC). The authors wish to thank all relevant institutions for providing data and giving support to this study.

${ }^{1}$ Research Institute for Fisheries and Enhancement Conservation 


\section{REFERENCES}

Amri, K. \& Agus, S.B. (2011). (In Indonesian). The state of coral reefs and waters around Thousand Islands Marine Protected Area and its preservation. In Suman, A., Wudianto and Sumiono, B. (Ed.) Fish resources in the Jakarta Bay and its alternative management. Research Institute for Marine Fisheries.

Anon. (2007). The Jakarta Bay, $80 \%$ of Pollution by Garbage from the Land. Accessed from http:www.kompas.com/kompas-cetak/0706/02/ metro/3570312.htm

Anon. (2011a). Aquaculture and rehabilitation of marine ecosystem programs. Thousand Islands. Sudin Kelautan \& Pertanian Kab. Adm. Kepulauan Seribu. DKI Jakarta

Anon. (2011b). Cultivation and marine ecosystem rehabilitation at the sea of Kepulauan Seribu, DKI Jakarta. Sudin Kelautan \& Pertanian Kab. Adm. Kepulauan Seribu. DKI Jakarta.

Anon. (2014). Statistics for capture fisheries DKI Jakarta Province, 2013. Jakarta Agency of Marine Affairs and Agriculture.

Arifin, Z. (2004). Local millenium ecosystem assessment: condition and trend of the greater Jakarta Bay Ecosystem. The Ministry of Environment, Republic of Indonesia. 30 pp.

Asriyana \& Salwiyah. (2007). Study on seagrass ecosystem in the Thousand Islands in WARTAWIPTEK, 15(2).

Atmaja S. B. (2011). (In Indonesian). An attempt towards sustainable fisheries management: Fragmentation of Jakarta Bay and Thousand Islands habitats. Jakarta Bay and Thousand Islands. In Suman, A., Wudianto and Sumiono, B. (Ed.) Fish Resources in the Jakarta Bay and its management alternatives. Research Institute for Marine Fisheries.

Bengen, D.G. (2000). (In Indonesian). Coastal and marine fisheries ecosystems, and integrated and sustainable management. Proceeding on Integrated Coastal Management Training. Center of Coastal and Marine Resources Assessment. Bogor Agricultural University.
Cesar. H. (1996). (In Indonesian). Economic analysis on indonesia coral reef. The World Bank. Indonesia.

Harian Pelita. (2015). Pollutant sources in the Jakarta Bay need to addressed systematically (Metropolitan). Tuesday Edition, 23 June 2015.

Hufiadi, Budiarti, T. W., Baihaqi \& Mahiswara. (2011). Fishing Capacity development in the Jakarta waters and its surrounding waters. In Suman, A., Wudianto and Sumiono, B. (Ed.) Fish Resources in the Jakarta Bay and its Management Alternative. Research Institute for Marine Fisheries.

Lestari \& Edward. (2004). (In Indonesia). The impact of heavy metal pollution on sea water quality and Fisheries Resources. (Study case on mass death of fish in the Jakarta Bay). Makara Sains. 8(2), 56-62.

Nuraini, S., Prihatiningsih, Wahyuningsih \& Wejatmiko. (2011). (In Indonesian). Utilization Status of shellfish in the Jakarta Bay and surrounding waters. In Suman, A., Wudianto and Sumiono, B. (Ed.) Fish Resources in the Jakarta Bay and its Management Alternative.Research Institute for Marine Fisheries.

Parawansa, I. (2007). (In Indonesian). The regime development policy of sustainable mangrove forest management in Teluk Jakarta. In Unpublished PhD. Thesis. Bogor Agricultural University, Bogor.

RCFMC. (2004). (In Indonesian). Final report on stock enhancement of holothuria scabra in the Thousand Islands, 2003 - 2004. Research Center for Fisheries Management and Conservation.

RIFEC. (2009). (In Indonesian). Final report on waters suitability for conservation of fish resources in the Jakarta Bay. Research Institute for Fish Stock Enhancement. Research Center for Capture Fisheries. Agendcy for Marine and Fisheries Research and Development.

RIFEC. (2010). (In Indonesian). Final report on stock enhancement of holothuria scabra in the thousand Islands, 2010. Research Institute for Fisheries Enhancement and Conservation, RCFMC.

Santoso, A.D. (2010). (In Indonesian). Coral reef condition in Karang Congkak Island, Thousand Islands. J. Hidrosfir Indonesia. 5 (2), 73-78. 
Soebagio. (2001). (In Indonesian). Suggestions and ideas on marine development on the Special Capital City District of Jakarta. Collection of scientific papers in urban areas and environments. III(2).

Suharsono, Giyanto, Yahmantoro, \& Munkajee, A.J. (1998). Changes of distribution and abundance of reef fish in Jakarta Bay and Seribu Islands. In. Proc. Coral Reef Evaluation Workshop, Pulau Seribu 11 - 20 Sept. 199, Jakarta, Indonesia, 37 $54 \mathrm{p}$.

Tandjung, S.D. (1982). The acute toxicity and histopathology of brook trout (Salvelinus fontinales, Mitchell) Exponed in Aluminium Acid Water. Ph.D Theisis New Cork: Louis Calder Conservation and Ecology Study Center of Fordham University.
Wagiyo, K. \& Hartati, S.T. (2013). (In Indonesian). Abundance and habitat condition of reef fish (Serranidae, Caesonidae and Scaridae) in the Thousand Islands. In Suman, A., Wudianto, Bintoro, G. and Haluan, J. (Ed.). Utilization Status of Fish Resources in the Java Sea. Research Institute for Marine Fisheries.

Williams, T.M., Rees, J.G., \& Setiapermana, D. (2000). Metals and trace organic compounds in sediments and waters of Jakarta Bay and the Pulau Seribu complex, Indonesia. Mar. Poll. Bull. 40(3), 277-285. 